\title{
PALEOLINEAMENTOS NA BACIA DO PARANÁ: FAVORABILIDADE PARA ACUMULAÇÕES DE PETRÓLEO

\author{
PAULO CESAR ARTUR
}

\author{
DISSERTAÇÃO DE MESTRADO - Programa de Pós-Graduação em Geologia - UFPR \\ DATA DE DEFESA: 31/08/98
}

A importância do papel desempenhado pelas estruturas tectônicas regionais de bacias intracratônicas, durante o processos de acumulação/retenção do petróleo em trapas estruturais, vem sendo enfatizada há tempo por diversos autores. As relações espaciais entre feições estruturais e áreas de ocorrência de campos de petróleo são muito bem documentadas em bacias produtoras. Na Bacia do Paraná, os programas exploratórios desenvolvidos até o momento não direcionam suas estratégias, priorizando a existência das grandes estruturas lineares reconhecidas na bacia. Neste trabalho foi testado um procedimento metodológico envolvendo estudos de análise de tendência e análise geoestatística de dados de espessura, tendo como objetivo identificar paleo-estruturas e direções controladoras da sedimentação e erosão/preservação das sequências tectonossedimentares que compõem o registro preservado da Bacia do Paraná. Para isso, foram selecionados pacotes limitados por superfícies discordantes ou de máxima inundação, os quais representam as partes inferiores e superiores dos registros Devoniano, Pensilvaniano-Permiano e Triássico Inferior. Para a parte inferior, foi investigada a tectônica formadora das sequências, enquanto que, para a parte superior, a tectônica modificadora. Essas seções foram delimitadas em perfis de poços para petróleo e com base na listagem de topo e base de formações, fornecidos pela Petrobrás. A análise de tendência, efetuada sobre os valores de espessura, permitiu reconhecer fenômenos de amplitude regional e, após sua retirada dos dados, foi possível avaliar, através da análise variográfica dos resíduos, as variações de espessura não relacionadas aos "trends" regionais. Para cada sequência analisada foram construídos semivariogramas direcionais, possibilitando a identificação das direções de maior e menor continuidade espacial. Com isso, foram reveladas as direções estruturais ativas em intervalos distintos de tempo geológico. Os parâmetros variográficos obtidos nas modelagens dos semiva-riogramas de cada sequência, foram adotados nas estimativas por krigagem dos dados de resíduo e, assim, feições morfológicas foram traçadas sobre os mapas gerados. Estas feições morfoestruturais, tais como gradientes anômalos, alinhamento de flexões nas curvas, alinhamento de narizes e depressões, foram traçadas manualmente e interpretadas como paleo-estruturas e paleolineamentos ativos na época de sedimentação dos pacotes sobre discordância e de erosão dos pacotes sob discordância. Procedimentos similares foram adotados para investigar a distribuição dos corpos intrusivos concordantes em meio aos pacotes sedimentares, tendo em vista sua possível associação com sistemas de falhas profundas durante o magmatismo e, portanto, com zonas mais quentes na época de geração e migração do petróleo. Os paleoli-neamentos foram, posteriormente, comparados com feições reveladas por tratamento similar de dados gravimé-tricos, a fim de associá-los com estruturas do embasa-mento. Finalmente, as paleo-estruturas, definidas nesse estudo, foram comparadas com estruturas identificadas por outro autores que utilizaram diferentes métodos, entre os quais sensoriamento remoto e magnetometria. Considerando-se, a princípio, a importância do controle dos paleolineamentos nas acumulações de petróleo, foi empregado um método de quantificação de favorabilidade baseado na análise probabilística condicional, com objetivo de investigar o poder destas estruturas como indicadores de zonas de alimentação dos sistemas acumuladores. Os resultados sugerem que as regiões mais favoráveis da bacia para o Sistema Petrolífero Ponta Grossa-Itararé estão relacionadas a paleolineamentos com direção nordeste, identificados no Devoniano e reativados até o recente. No Sistema Petrolífero Irati-Rio Bonito/Tietê, as áreas mais favoráveis estão relacionadas às falhas com direção nordeste, ativas entre os períodos Triássico e Juro-Cretáceo, adicionalmente às regiões que sofreram aquecimento anômalo devido à intrusão de maiores espessuras de corpos intrusivos em meio às rochas geradoras. 